\title{
Indonesian natural rubber export potential in European market
}

\author{
Aura Dhamira ${ }^{1}$ and Imade Yoga Prasada ${ }^{2}$ \\ ${ }^{1}$ Graduate Student, Faculty of Agriculture, Universitas Gadjah Mada \\ ${ }^{2}$ Study Program of Agribusiness, Faculty of Science and Technology, Universitas Putra Bangsa, Jl \\ Ronggowarsito No. 18 Kebumen 54361, Indonesia
}

\begin{abstract}
Indonesia is one of the largest natural rubber exporters in the world. On the other hand, the potential for natural rubber in the world market is enormous. The Asian continent is the largest market for Indonesian natural rubber, followed by American and European markets. Currently there have been many studies on the competitiveness of Indonesian natural rubber exports to the international market, but so far there has not been much research on the competitiveness and potential of rubber exports specifically to European countries. This study aims to determine the competitiveness and the potential of Indonesian natural rubber in European countries, namely Germany, France, and Spain. The method used in this study is descriptive analytics, meanwhile Revealed Comparative Advantage (RCA) was used to determine Indonesia's competitiveness in each of the partner countries, on the other hand Export Product Dynamic (EPD) was used to determine the performance of Indonesian natural rubber in partner countries. The RCA index shows that Indonesia has competitive advantages in the partner countries, and the EPD matrix indicated that Indonesia is in a rising star position in the German, French and Spanish markets. To strengthen this position, Indonesia needs to increase their export value through the increase in production.
\end{abstract}

\section{Introduction}

Indonesia is one of the biggest rubber exporters in the world, in 2019, 2.503.671 tons of natural rubber is exported from this country [1]. Indonesia is recorded to have contributed 28.06 percent of the world's total natural rubber supply in the same year [2]. This contribution is the second largest contribution after Thailand (32.94 percent). Indonesia's natural rubber exports have also shown positive performance in the last five years. The growth of Indonesia's natural rubber exports increased by 1 percent in the 2015 to 2019 period. The growth of Indonesia's natural rubber exports was much better than Thailand's negative export growth in the same period.

The potential for natural rubber in the world market is enormous, given the large number of potential markets, especially for industrial purposes. Currently, the Asian continent is the largest market for Indonesian natural rubber with the highest volume and value of natural rubber exports, namely 1,262,855 tons and USD 1,777,965,000, respectively. This is followed by markets in the United States and Europe, where the export 
values of both are USD 1,099,732,000 and USD 591,476,000, respectively. Some of the countries that are the main markets for Indonesian rubber exports include the United States, Japan, and China [1]. However, there are 9 out of 15 main export destination countries that still have great potential to become Indonesia's rubber export markets, namely Singapore, South Korea, Canada, the Netherlands, France, England, Spain, Italy. and Belgium [3].

Several studies have stated that Indonesian rubber products have a comparative advantage in the international market $[4,5]$. It was further stated that among the four main world rubber exporting countries (Thailand, Malaysia, Vietnam, and Indonesia), two countries, namely Thailand and Indonesia had the highest RCA values for overall rubber exports. Currently there have been many studies on the competitiveness of Indonesian natural rubber exports to the international market, but there has not been much research on the competitiveness and potential of rubber exports from Indonesia to European countries, so this research is urgent to be carried out. The use of Revealed Comparative Advantage (RCA) and Export Product Dynamic (EPD) methods are expected to show the competitiveness and performance of rubber commodities in the markets of European countries.

\section{Material and methods}

This research uses descriptive analytical method which aims to be able to provide a systematic description of the facts and characteristics of the object or subject accurately. Data sourced from Eurostat is used in this study, these data are monthly data on rubber exports with HS code 4001 from Indonesia and the world to the three main partner countries on the European continent, namely Germany, France and Spain from 1989 to 2020. Those partner countries were chosen because the average export value of Indonesian natural rubber to these three countries is the highest in the European market.

In this study, two analyses were carried out, namely Revealed Comparative Advantage (RCA) and Export Product Dynamic (EPD). The RCA analysis was chosen to determine Indonesia's competitiveness in each of these countries, while the EPD was used to determine the performance of Indonesian natural rubber in partner countries in Europe. RCA is a relative measure indicating a strong focus on some sectors but less on others [6]. The formula for measuring RCA is as follows:

$$
R C A=\frac{x_{a j} / x_{t j}}{w_{a j} / W_{t j}}
$$

where $X_{a j}$ are exports of commodity a from Indonesia to country $j$ and $X_{t j}$ represents the total exports from Indonesia to country $\mathrm{j}$, meanwhile $\mathrm{W}_{\mathrm{aj}}$ is the world exports of commodity a to country $\mathrm{j}$ and $\mathrm{W}_{\mathrm{tj}}$ shows the total of world exports to country $\mathrm{j}$. A comparative advantage is "revealed" if RCA $>1$. If RCA is less than one, the country is said to have a comparative disadvantage in the commodity or industry [7].

EPD method is used to determine the dynamic movement of a commodity, whether the competitiveness of a product has dynamic performance (has fast growth) or not. If the commodity's growth is above the world average and this situation continues in the long term, then this commodity can eventually become an important source of a country's export income [8]. The results of calculations using the EPD are then analysed using a matrix consisting of growth in product market share and growth in export market share. The EPD matrix contains four possible outcomes, namely Rising Star, Falling Star, Lost Opportunity and Retreat. The EPD matrix is described as follows: 


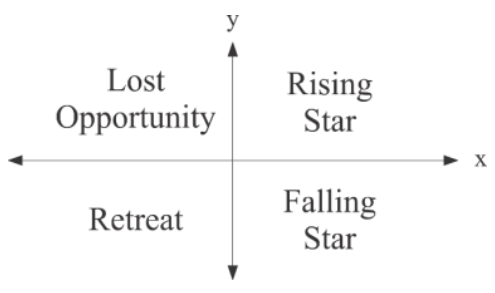

Fig. 1. EPD Matrix

Meanwhile, the formula for calculating this method is as follows:

$\mathrm{X}$-axis (export market share growth):

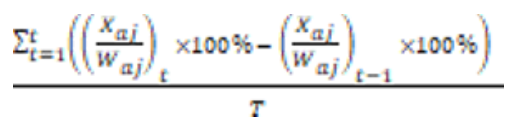

Y-axis (product market share growth):

$$
\frac{\sum_{t=1}^{t}\left(\left(\frac{X_{t j}}{W_{t j}}\right)_{t} \times 100 \%-\left(\frac{X_{t j}}{W_{t j}}\right)_{t-1} \times 100 \%\right)}{\tau}
$$

Where $X_{a j}$ is the value of commodity exports a from Indonesia to country $j, W_{a j}$ is the value of world commodity exports a to country $\mathrm{j}, \mathrm{X}_{\mathrm{tj}}$ is the total value of exports from Indonesia to country $\mathrm{j}, \mathrm{W}_{\mathrm{tj}}$ is the total value of world exports to country $\mathrm{j}$, and $\mathrm{T}$ is the number of years [8].

\section{Results and discussions}

\subsection{The competitiveness of Indonesian natural rubber in European countries}

The competitiveness of Indonesian natural rubber in the markets of several European countries (Germany, France, and Spain) can be seen using the RCA method analysis. This method measures the performance of Indonesia's natural rubber exports in the markets of these three countries by evaluating the role of rubber exports in Indonesia's total exports compared to the natural rubber market share in trade in these respective countries. The development of Indonesia's RCA index to Germany, France and Spain can be seen in the following figures. 


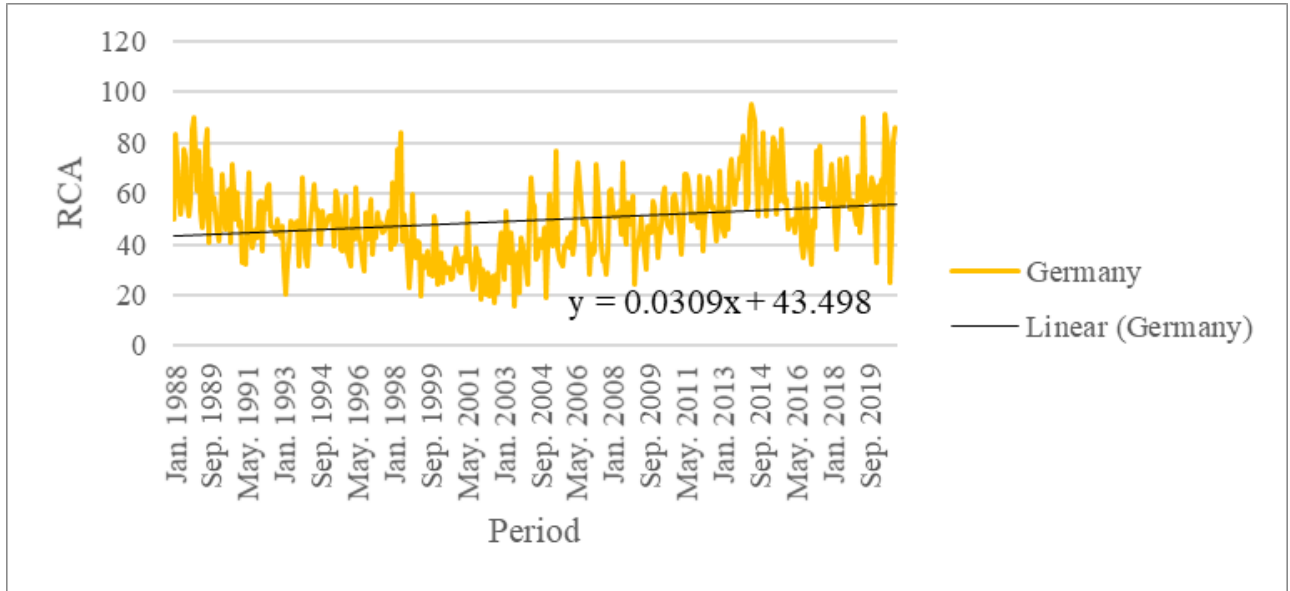

Fig. 2. Development of Indonesia's RCA Index in the German Market Source: Eurostat (compiled), 2021

Figure 2 shows that the development of the RCA index for natural rubber commodities from Indonesia to Germany fluctuates in each period, with an increasing trend through the years. Based on the linear equation of the RCA index development chart, there is an increase in the RCA index of 0.0309 every month, while the average RCA index for Indonesia in the German market is 49.62. This value shows that Indonesian natural rubber competitiveness is above the world average in the German market, which is shown by the share of export value where Indonesia's share of export value is higher than the world's (Figure 3).

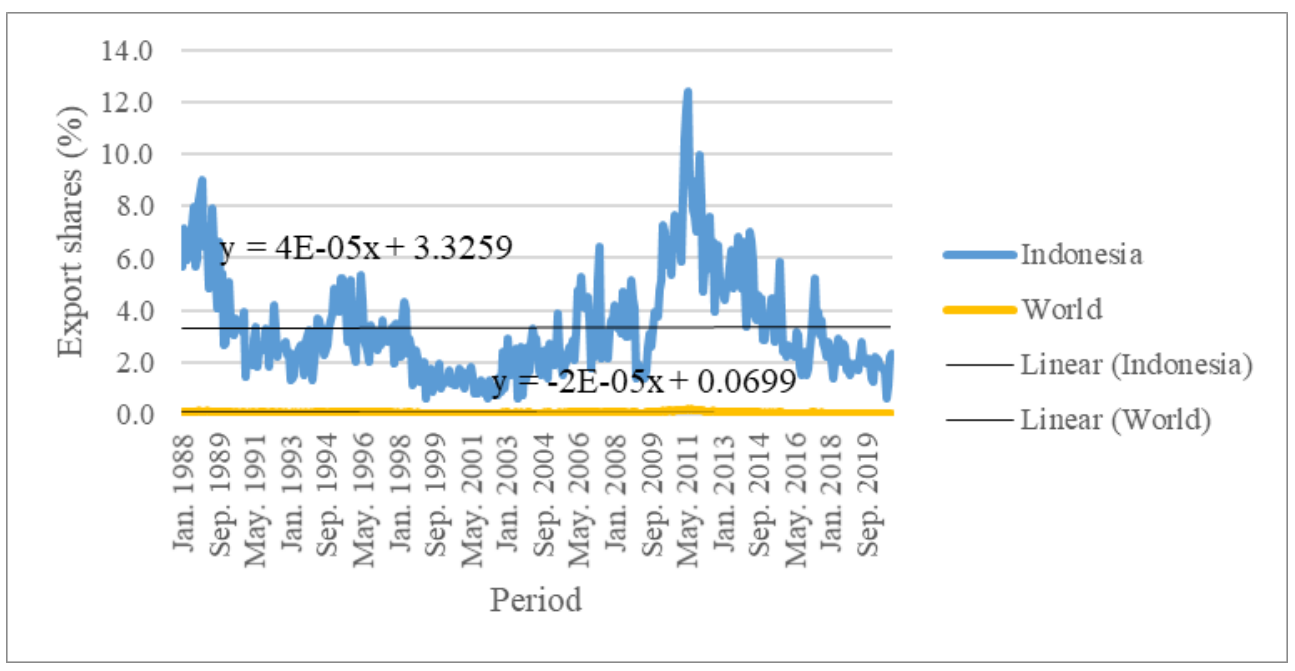

Fig. 3. Share of Export Value of Natural Rubber in the German Market Source: Eurostat (compiled), 2021

Figure 3 shows the comparison between the share of natural rubber exports from Indonesia and the world to the Germany market every month for 32 years. The share of Indonesia's export value fluctuates every month, but if seen from the equation in the figure, it can be concluded that the share of the export value of natural rubber from Indonesia has 
increased slightly every month, while the share of world exports tends to decline. This can be interpreted as a good opportunity, where if the share of Indonesia's export value continues to increase, and the world continues to decline, then Indonesia's position for natural rubber exports in the German market will be even stronger. Meanwhile the development of Indonesia's RCA index in the French market can be seen in Figure 4.

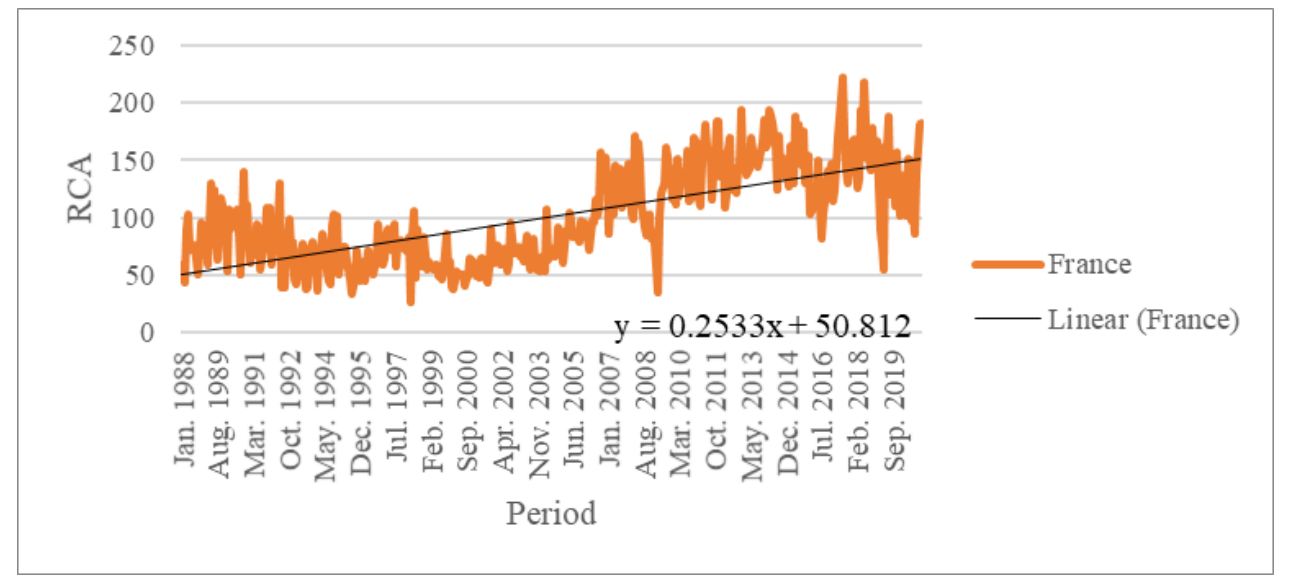

Fig. 4. Development of Indonesia's RCA Index in the French Market Source: Eurostat (compiled), 2021

Figure 4 illustrates the development of Indonesia's RCA index in the French market. This index fluctuates from time to time. The highest RCA index achieved in June 2014, and the lowest RCA index happened in March 1998. The coefficient in the linear equation shows positive value, namely 0.2533 , it means that the RCA index of Indonesian natural rubber in the French market increases by 0.2533 every month with an average index of 101.09 which means that Indonesian natural rubber also has a fairly strong position in the French market. This is supported by the share of Indonesia's export value which is higher than the share of world export value which can be seen in Figure 5.

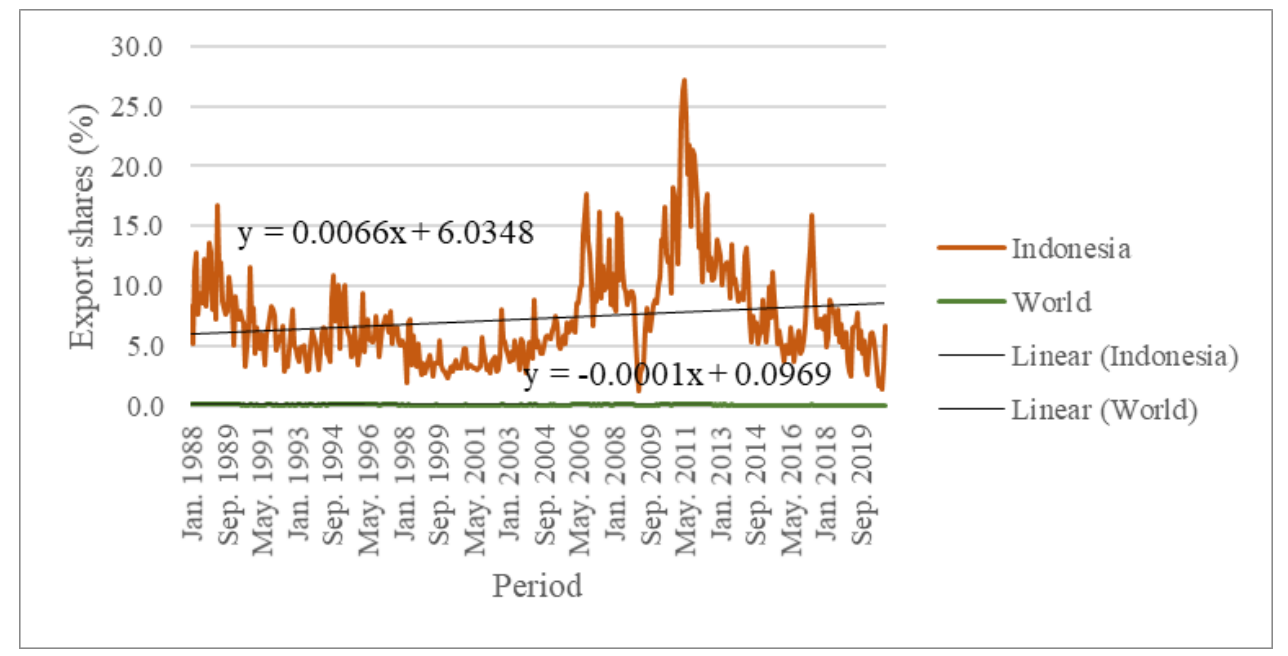

Fig. 5. Share of Export Value of Natural Rubber in the French Market Source: Eurostat (compiled), 2021 
The share of the export value of Indonesian natural rubber is higher than the share of the export value of world natural rubber, it means that Indonesia does have a competitiveness for this commodity in the French market. Information regarding the development of the share of the export value of natural rubber in Indonesia and the world can also be seen in Figure 5.

The development of the share of the export value of natural rubber in Indonesia fluctuates with a positive trend, while the share of the export value of natural rubber in the world tends to be negative, as shown by the coefficient obtained from the linear equation. Based on the equation, the coefficient for the development of the share value of Indonesia's natural rubber exports to France is 0.0066 , which means that there is an increase in the share value of natural rubber exports from Indonesia by $0.0066 \%$ every month. The increase in the share value of Indonesia's natural rubber exports followed by a decrease in the share value of world natural rubber exports is a good opportunity for Indonesia to strengthen its position in the French market. To strengthen its position, Indonesia needs to improve the quality of its natural rubber products, an increase in production is also needed.

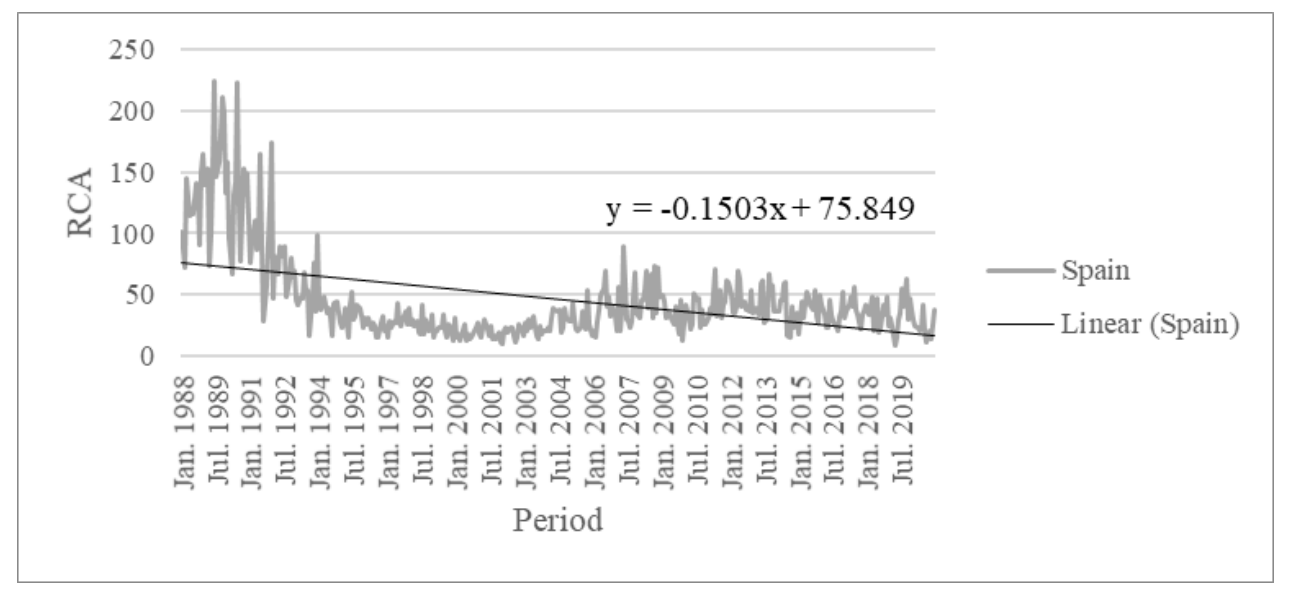

Fig. 6. Development of Indonesia's RCA Index in the Spanish Market Source: Eurostat (compiled), 2021

Unlike the two previous countries, the RCA index for Indonesian natural rubber to the Spanish market decreased by 0.1503 per month with an average RCA of 46.02 . The decrease of Indonesian natural rubber product competitiveness and the poor market distribution results in the decline of natural rubber export growth [9]. Based on this condition, they concluded that Indonesian natural rubber quality is still low, thus the importer countries alter their importing activity from other countries. This value is lower than the RCA for natural rubber from Indonesia to Germany and France. Even though it has decreased, this index still shows that Indonesian natural rubber has competitiveness in the Spanish market, this can be seen from the RCA index which is still worth greater than 1 . In addition, the share of the value of Indonesia's natural rubber exports to Spain is still higher than with the share of world export value for the same commodity. This comparison can be seen in Figure 7. 


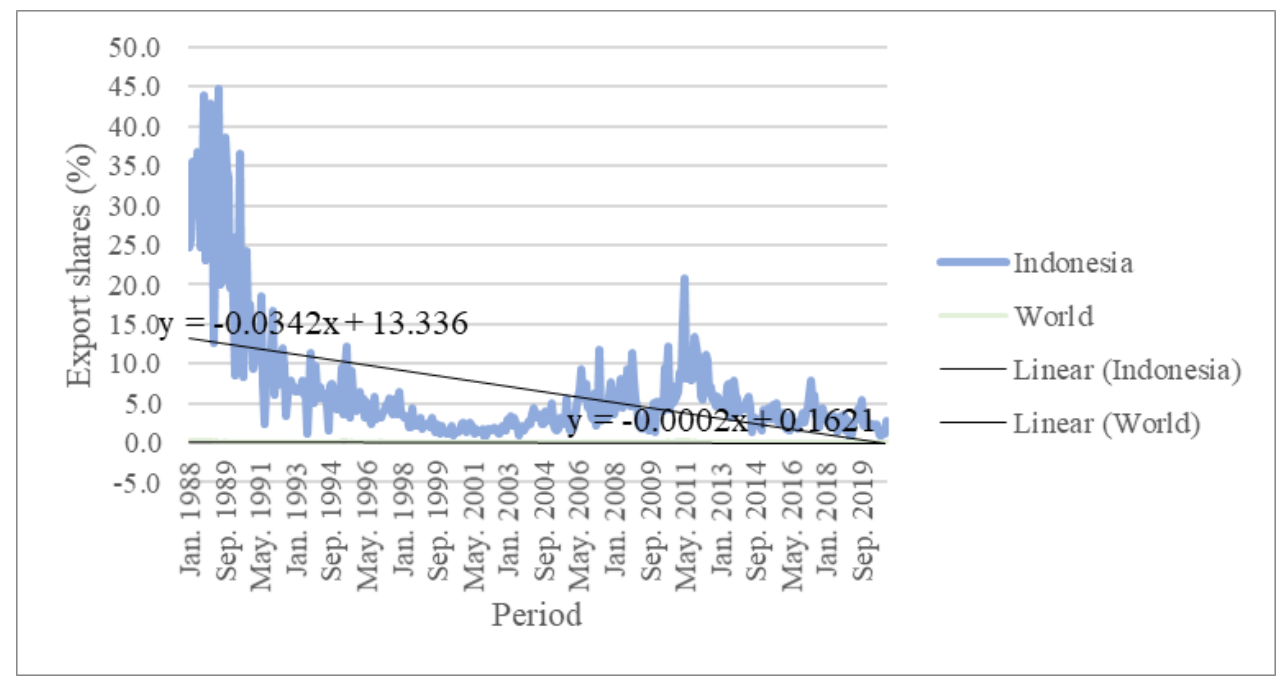

Fig. 7. Share of Export Value of Natural Rubber in the Spanish Market Source: Eurostat (compiled), 2021

Figure 7 shows the development of the share value of Indonesia's natural rubber exports to Spain has fluctuated with a tendency to decline. This is also supported by a linear equation which shows a coefficient of -0.0342 , which means that the share of Indonesia's export value to Spain decreases by $0.0342 \%$ every month. The decline in the competitiveness of Indonesia's natural rubber is likely due to the sluggishness of the domestic rubber industry because of the low price of natural rubber in the world [4]. On the other hand, the share value of world natural rubber exports to Spain has also decreased, amounting to $0.0002 \%$ every month. This decline will have an unfavourable impact for Indonesia, because if the share value of Indonesia's natural rubber exports in the Spanish market continues to decline, with a percentage decrease that is greater than the percentage share of world export value, then there is a possibility that Indonesia will lose its comparative advantage in the Spanish market. Even so, for now the share of Indonesia's natural rubber export value is still higher than the share of world export value, so that Indonesian natural rubber still has comparative competitiveness in the Spanish market.

\subsection{The position of Indonesian natural rubber in European countries}

The Export Product Dynamic (EPD) analysis in this study is used to determine Indonesia's position in the natural rubber trade in the German, French, and Spanish markets. a product is said to be dynamic if its market share grows faster than the world average. The results of EPD calculations can be seen in table 1 .

Table 1. EPD calculation results for Indonesian natural rubber exports to Germany, France and Spain

\begin{tabular}{|l|c|c|c|}
\hline Partner Country & $\begin{array}{c}\text { Export Market Share } \\
\text { Growth }(\%)(\mathrm{x})\end{array}$ & $\begin{array}{c}\text { Product Market } \\
\text { Share Growth }(\%) \\
(\mathrm{y})\end{array}$ & EPD \\
\hline Germany & 3.771 & 1.116 & Rising star \\
\hline France & 2.679 & 1.872 & Rising star \\
\hline Spain & 3.823 & 7.932 & Rising star \\
\hline
\end{tabular}


Table 1 shows the average EPD of Indonesia's natural rubber exports to three partner countries in the European continent. The EPD analysis shows the dynamics of export growth in a certain period which categorized in four market positions, namely rising star, falling star, lost opportunity dan retreat. Rising star is the most ideal and desired position, while retreat is the most undesired position because it means that the product or the commodity is not wanted in the market anymore [10]. Indonesian natural rubber export market share growth in German and French market are higher than the product market share growth, meanwhile the export market share growth in the Spanish market is lower than its growth of product market share. Based on table 1, Indonesia is in a rising star position in the German, French, and Spanish markets. This shows that Indonesian natural rubber products are dynamic products in these three countries. It can also be concluded that Indonesian natural rubber products have increased market share in Germany, France, and Spain, in other words Indonesian natural rubber commodities are in an ideal market position marked by a rapidly growing export share. We also can conclude that Germany, France, and Spain are the potential markets for Indonesian natural rubber.

\section{Conclusions}

Indonesian natural rubber has a comparative advantage in the German, French, and Spanish market with the RCA $>1$. The natural rubber products are dynamic products in these three countries, it can be seen from the result of EPD matrix where Indonesia is in the rising star position. To maintain this position, Indonesia needs to increase the export value of natural rubber, by increasing its quality and quantity in European market.

\section{References}

1. Badan Pusat Statistik. Indonesian Rubber Statistics 2019. Jakarta (2019).

2. Trademap. List of importing markets for a product exported by Indonesia, Thailand, Malaysia. Product: 400122 Technically specified natural rubber 'TSNR,'. List of Importing Market (2021). [Online] from https://www.trademap.org/. [Accessed on 21-Mar-2021].

3. M. B. Lembang and Y. Pratomo. Trikonomika. 12, 1:20-31(2013). [Bahasa Indonesia]

4. R. Kamaludin. Sriwij. Int. J. Dyn. Econ. Bus. 2, 1:85-98(2018).

5. D. Sattayawaksakul and S. Y. Choi. A comparative analysis of export competition in natural rubber among the leading exporters in Southeast Asia. SSRN. 1(2017). doi: http://dx.doi.org/10.2139/ssrn.3010865.

6. K. Laursen. Eurasian Bus. Rev. 5, 1:99-115(2015). doi: 10.1007/s40821-015-00171.

7. D. Granabetter. Rev. Innov. Compet. 2, 2:97-114(2016). doi: 10.32728/ric.2016.22/3.

8. E. Nurhayati, S. Hartoyo, and S. Mulatsih. J. Ekon. dan Pembang. Indones. 19, 2:173-190(2019). doi: 10.21002/jepi.v19i2.847. [Bahasa Indonesia].

9. F. Zuhdi and R. S. Anggraini. International Journal of Agriculture System. 8, 2:130-139(2020). doi: 10.20956/ijas.v8i2.2518.

10. G. Muharami and T. Novianti. J. Agribisnis Indones. 5, 2:87-104(2018). doi: 10.29244/jekp.5.2.87-104. [Bahasa Indonesia]. 